\title{
PEMANFAATAN YOUTUBE UNTUK MEMPEROLEH PASSIVE INCOME BAGI PENGAJAR DI AKN KAJEN
}

\author{
Imam Prayogo Pujiono ${ }^{1}$ \\ ${ }^{1}$ Program Studi Diploma 2 Teknik Informatika Politeknik Negeri Bandung \\ Email: imamprayogopujiono@gmail.com
}

\begin{abstract}
Abstrak
Pengajar merupakan bagian dari masyarakat yang memiliki tugas penting dan berat yaitu mencetak Sumber Daya Manusia (SDM) yang unggul. Beratnya tugas pengajar tak lepas dari beragam tantangan yang dihadapi, salah satunya adalah rendahnya penghasilan para pengajar sehingga mereka tidak fokus dalam mengajar / menyiapkan bahan ajar karena seringkali harus mencari penghasilan tambahan di bidang lain untuk mencukupi kebutuhan hidupnya. AKN Kajen adalah pendidikan vokasi jangka pendek yang berorientasi terhadap perluasan lapangan kerja. Dalam hal ini, pengajar AKN Kajen memiliki tugas dan tantangan yang berat seperti yang telah disebutkan, sayangnya beratnya tugas dan tantangan tersebut tidak diimbangi dengan penghasilan yang didapat. Youtube adalah sebuah situs website berbagi video terbesar di dunia. Selain sebagai media berbagi video youtube juga dapat dimanfaatkan sebagai media pembelajaran, salah satu kelebihan media pembelajaran melalui youtube jika dibanding menggunakan media konvensional seperti buku adalah: lebih memvisualisasikan materi yang diajarkan. Selain itu video yang di upload di youtube juga berpotensi menghasilkan uang / passive income. Pada program pengabdian kepada masyarakat ini dilakukan pelatihan dan pendampingan kepada pengajar AKN Kajen untuk memanfaatkan Youtube dalam mencari penghasilan tambahan / passive income. Kegiatan pelatihan ini dilaksanankan selama 2 hari, sedangkan kegiatan pendampingan dilaksanakan selama 2 bulan, selain itu peserta kegiatan (mitra) juga mendapat modul pelatihan dalam bentuk video. Modul pelatihan yang diberikan pada pelatihan ini dinilai baik, hal ini terbukti sebanyak $76 \%$ peserta pelatihan dapat mempraktekkan sendiri materi yang ada dalam modul tersebut. Kegiatan pelatihan ini juga dinilai bermanfaat, karena $85 \%$ peserta menganggap pelatihan ini membantu mereka mencari penghasilan tambahan melalui youtube. Dengan adanya pelatihan ini diharap Pengajar dapat memanfaatkan youtube sebagai media pembelajaran dan juga untuk mencari passive income.
\end{abstract}

Kata kunci: Youtube, passive income, pengajar, AKN Kajen 


\section{PENDAHULUAN}

Pengabdian kepada masyarakat (PM) adalah salah satu tridharma perguruan tinggi yang wajib dikerjakan oleh seluruh staf pengajar (dosen). Secara sederhana kegiatan pengabdian kepada masyarakat dapat didefinisikan sebagai program-program yang ditujukan untuk menyelesaikan semua permasalahan yang ada di masyarakat. Masyarakat dalam hal ini dapat diartikan secara luas, yaitu masyarakat umum, industri, dan pengusaha kecil dan menengah.

Pengajar merupakan bagian dari masyarakat yang memiliki tugas penting dan berat yaitu mencetak Sumber Daya Manusia (SDM) yang unggul sehingga dapat mensejahterakan masyarakat dan memajukan bangsa. Beratnya tugas pengajar tak lepas dari beragam tantangan yang harus dihadapi, misalnya didalam sekolah tantangan terbesar mereka adalah siswa yang sulit menangkap materi yang diajarkan terutama jika media pembelajaran yang disediakan tidak maksimal dalam mendukung proses belajar mengajar seperti tidak mampu memvisualisasikan materi yang diajarkan. Sedangkan tantangan terbesar mereka diluar sekolah adalah rendahnya penghasilan para pengajar terutama bagi mereka yang berstatus bukan Pegawai Negeri Sipil (PNS) atau bagi mereka yang bekerja di sekolah swasta sehingga mereka tidak fokus dalam mengajar / menyiapkan bahan ajar karena seringkali harus mencari penghasilan tambahan di bidang lain untuk bisa mencukupi kebutuhan hidupnya.

AKN Kajen adalah pendidikan vokasi jangka pendek yang berorientasi terha- dap perluasan lapangan kerja di daerah maupun didunia industri dan dunia usaha [1]. Dalam hal ini, pengajar $\mathrm{AKN}$ Kajen yang berjumlah sebanyak 16 orang memiliki tugas dan tantangan yang berat seperti yang telah disebutkan di atas, sayangnya beratnya tugas dan tantangan tersebut tidak diimbangi dengan besarnya penghasilan yang didapat, yang hanya sebesar 2.500 .000 perbulan, sehingga banyak pengajar di AKN Kajen mencari penghasilan tambahan di bidang lain untuk mencukupi kebutuhan hidupnya.

Youtube merupakan sebuah situs website media berbagi video online terbesar dan paling populer di dunia internet [2]. Selain sebagai media berbagi video youtube juga dapat dimanfaatkan sebagai media pembelajaran terutama pada mata pelajaran yang berbasis praktikum, salah satu kelebihan media pembelajaran youtube jika dibanding menggunakan media pembelajaran konvensional seperti buku adalah:

a. Lebih memvisualisasikan materi yang diajarkan, misalkan saat praktikum pembuatan kabel LAN siswa akan mudah memahami jika bahan ajar diberikan dalam bentuk video karena lebih memvisualisasikan materi yang sedang dibahas [3].

b. Mudah diakses dari mana saja, siswa dapat mengakses sebuah materi yang diberikan pengajar dari mana saja dan kapan saja [4].

c. Lebih interaktif, karena youtube memfasilitasi siswa dan pengajar untuk berdiskusi ataupun melakukan tanya jawab pada sebuah video pembelajaran atau pada sebuah kolom diskusi secara langsung [4]. 
DIFUSI

Volume 3, No.1 Januari 2020

Selain itu video yang di upload di youtube juga berpotensi menghasilkan passive income bagi orang yang meng-upload-nya. Asal channel youtube orang yang meng-upload telah memenuhi ketentuan youtube. Passive income sendiri dapat diartikan sebagai pemasukan yang diperoleh walaupun kita tidak bekerja lagi, sehingga yang bekerja adalah asset kita [5].

Pemanfaatan Youtube untuk memperoleh passive income perlu diajarkan kepada pengajar khususnya pengajar di AKN kajen karena selain bisa mendapat penghasilan tambahan berupa passive income, para pengajar juga bisa memanfaatkan youtube sebagai media pembelajaran yang tentunya memiliki beberapa kelebihan dibanding menggunakan media pembelajaran konvensional seperti buku.

\section{METODE}

Pada program pengabdian kepada masyarakat ini memakai metode pelatihan dan pendampingan yang melewati beberapa tahapan. Adapun tahapan pelatihan ini ditunjukan pada diagram alir Gambar 1 .

Beberapa metode yang digunakan dalam pelatihan pada pelaksanaan kegiatan pengabdian kepada masyarakat ini yaitu sebagai berikut.

a. Metode ceramah; metode ini dipakai saat penyajian materi dalam bentuk pemaparan pengetahuan dan pemahaman teoritis tentang cara menjadi youtuber, cara mencari bahan video yang bebas lisensi, cara editing audio, cara editing video, cara SEO di youtube dan cara monetisasi di youtube.

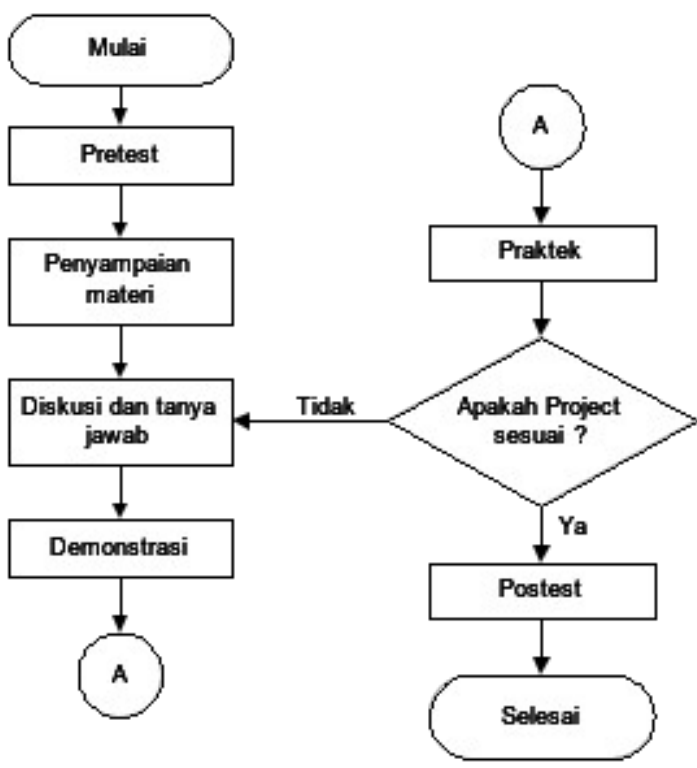

Gambar 1. Diagram alir pelatihan

b. Metode diskusi dan tanya jawab; metode ini dipakai untuk mengetahui pemahaman mitra secara umum serta memotivasi mitra tentang pentingnya pemanfaatan youtube untuk memperoleh passive income bagi pengajar di AKN Kajen.

c. Metode demonstrasi; metode ini dipakai untuk menyampaikan trik dan tips saat menggunakan youtube untuk memperoleh passive income.

d. Interaksi langsung; dikemas dalam bentuk workshop sehingga bisa langsung mempraktekkan materi yang diberikan.

e. Metode evaluasi; digunakan untuk menilai pengetahuan mitra terhadap materi yang akan/sudah diajarkan.

Tahapan metode evaluasi dalam kegiatan pelatihan ini meliputi evaluasi di awal dan akhir kegiatan. Pretest diberikan kepada mitra untuk mengukur kemampuan awal, terutama pengetahuan 
dan pemahaman tentang pemanfaatan youtube untuk memperoleh passive income. Hasil evaluasi, dipakai untuk mengetahui dari mana awal pemberian materi agar materi yang diberikan dapat sesuai dengan kemampuan awal mitra. Post test diberikan diakhir pelatihan kepada mitra untuk mengetahui hasil dari pemahaman tentang pemanfaatan youtube untuk memperoleh passive income. Kegiatan pelatihan ini dilaksanakan selama 2 hari dan dilaksanakan bertempat di AKN Kajen. Selanjutnya setelah pelatihan selesai dilakukan, maka dilanjutkan dengan tahap pendampingan yang dilakukan melalui grup whatsapp dengan cara tanya jawab dan memberikan masukan terhadap channel yang telah dibuat oleh peserta.

\section{HASIL DAN PEMBAHASAN}

Berdasarkan pengabdian kepada masyarakat mengenai pelatihan pemanfaatan youtube untuk memperoleh passive income bagi pengajar AKN Kajen yang sudah dilaksanakan, diperoleh hasil sebagai berikut.

Hasil dari kegiatan pengabdian yang sudah dilaksanakan:

1. Pihak mitra (peserta) dapat merespon dengan baik dan juga berperan aktif dalam mengikuti pelatihan dan pendampingan yang telah dilakukan.

2. Materi pelatihan yang diberikan kepada mitra, mulai dari cara menjadi content creator youtube, mencari bahan ajar yang baik, editing audio dengan audacity, editing video dengan filmora, monetisasi di youtube dan teknik SEO di youtube merupa- kan hal yang baru bagi mereka dan sangat dibutuhkan dalam memanfaatkan youtube untuk memperoleh passive income.

3. Modul pelatihan yang telah diberikan pada pelatihan ini dinilai baik, hal ini terbukti sebanyak $76 \%$ peserta pelatihan dapat mempraktekkan sendiri materi yang diberikan setelah mempelajari modul tersebut.

4. Kegiatan pelatihan ini memberikan ilmu baru kepada peserta, karena sebesar $73 \%$ peserta baru mengerti cara memperoleh passive income dari youtube setelah mengikuti pelatihan ini.

5. $85 \%$ peserta menganggap bahwa pelatihan ini bermanfaat untuk membantu mencari penghasilan tambahan melalui youtube.

Kegiatan pengabdian masyarakat dimulai dari pengajuan proposal pada tanggal 17 Mei 2019. Pelaksanaan pelatihan pemanfaatan youtube untuk memperoleh passive income bagi pengajar AKN Kajen dilaksanakan sebanyak 2 kali, yaitu pada tanggal 26 September 2019 dan 10 Oktober 2019 di kampus AKN Kajen.

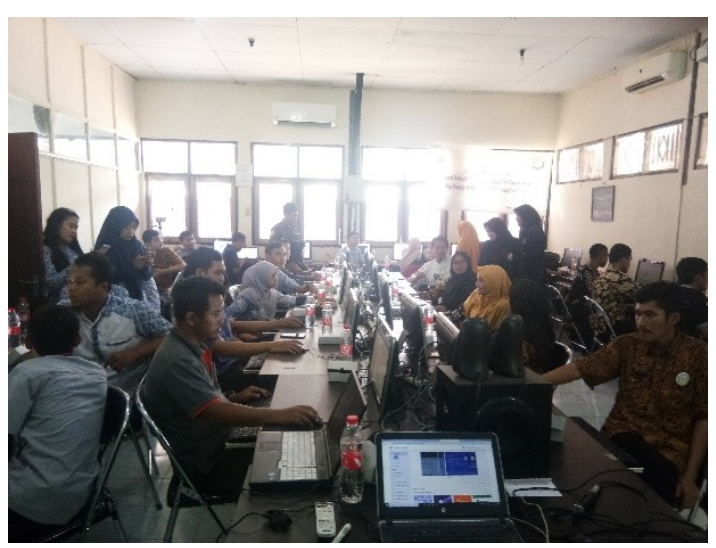

Gambar 2. Pelaksanaan pelatihan pemanfaatan youtube di AKN Kajen. 
Setelah pelatihan selesai, selanjutnya diadakan pendampingan selama 2 bulan melalui media grup Whatsapp dengan cara tanya jawab dan memberikan masukan terhadap channel yang telah dibuat oleh peserta pelatihan.

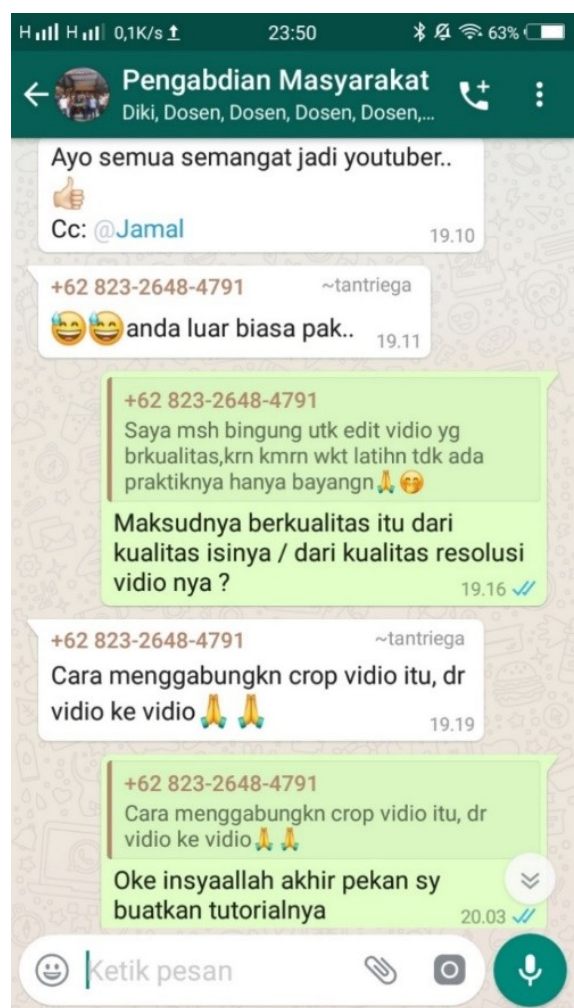

Gambar 3. Pendampingan peserta pelatihan melalui grup Whatsapp

\section{KESIMPULAN}

Dari pelaksanaan pelatihan pengabdian masyarakat terhadap pengajar di $\mathrm{AKN}$ Kajen dalam memanfaatkan youtube untuk memperoleh passive income bagi pengajar AKN Kajen, dapat kami simpulkan bahwa program pengabdian ini dapat memberikan manfaat dan tepat sasaran. Bentuk pelatihan dan pendampingan seperti ini ialah bentuk yang sangat efektif untuk memberikan skill tambahan bagi mintra agar dapat memanfaatkan Youtube untuk memperoleh passive income.

Sesuai dengan hasil evaluasi yang sudah dilaksanakan, terdapat beberapa saran untuk pelaksanaan pengabdian masyarakat kedepannya yaitu sebagai berikut:

a. Durasi pelaksanaan pelatihan sebaiknya dibuat lebih panjang, yang semula 4 jam tiap pertemuan menjadi 6 jam tiap pertemuan agar para peserta memiliki waktu yang lebih panjang dalam mempraktekkan materi yang diberikan.

b. Dalam pelaksanaan pengabdian masyarakat terutama yang sangat membutuhkan internet, sebisa mungkin dilaksanakan pada lokasi pelatihan yang koneksi internetnya sangat bagus dan peserta juga dihimbau untuk menyediakan koneksi internet sendiri sebagai koneksi cadangan. Sehingga para peserta tidak terkendala dalam pelatihan tersebut.

\section{UCAPAN TERIMAKASIH}

Program. Pengabdian kepada Masyarakat ini didukung oleh dana DIPA Politeknik Negeri Bandung. Penulis mengucapkan terima kasih atas pendanaan yang telah diberikan.

\section{REFERENSI}

[1] http://smkmusi.sch.id/hal/visi-danmisi (diakses pada 15 mei 2019), 2019.

[2] C. Snelson, Youtube across the Disciplines: A Review of Literature. MERLOT Journal of Online 
DIFUSI

Volume 3, No.1 Januari 2020

Learning and Teaching Vol. 7, No. 1, Maret, 2011.

[3] I. K. Suma, I. W., Sadia, I. W., Iwantara, Pengaruh Media Video Youtube pada Pembelajaran IPA terhadap Motivasi Belajar dan Pemahaman Konsep Siswa, eJournal Program Pascasarjana Universitas Pendidikan Ganesha, Vol. 4, Bandung, 2014.
[4] D. Retno, Pemanfaatan Youtube sebagai Media Pembelajaran dalam Meningkatkan Kreatifitas Guru Bahasa lnggris Mts AI-Insan. Seminar Nasional PGMI UIKA, Bogor, 2018.

[5] S. Wiyono, Manajemen Potensi Diri. Jakarta: PT. Grasindo. 2016. 